\title{
Implementasi Pola Pemuridan Yesus Menurut Injil Matius
}

\author{
Johannes Sembiring \\ Sekolah Tinggi Teologi Imanuel Ministry Elshaddai Langkat, Sumatera Utara \\ jsembiring366@hotmail.com
}

\begin{abstract}
Matthew does not emphasize the apostle's understanding of Jesus' disciples in his writings, but instead uses the term "disciple." Matthew, dealing with Jews who are peculiar to discipleship, certainly considers the root importance of the term "disciple", a learner. A person who serves God should be a disciple of Christ, who loves and follows Christ and lives according to the character of the Lord Jesus with all his heart. This is a literature review article that uses descriptive methods. Descriptive study was applied to the pastors of the GPdI session in Jember Regency which numbered 28 people as participants. Research data obtained directly from the field using research instruments in the form of a questionnaire. After analyzing to get answers based on the percentage of participant scores, it can be concluded that the implementation value of Jesus' discipleship pattern according to the Gospel of Matthew among the Pastors of the GPdI Session in Jember district is very high, namely $90.30 \%$.
\end{abstract}

Keywords: pastor; serve; discipleship; discipleship pattern

\begin{abstract}
Abstrak
Matius tidak menekankan tentang pemahaman rasul pada murid-murid Yesus pada Tulisannya, akan tetapi menggunakan istilah "murid." Matius berhadapan dengan orang Yahudi yang khas dengan pemuridan, pasti menganggap penting akar istilah "murid" tersebut, yaitu seorang yang belajar. Seorang yang melayani Tuhan seharusnya adalah seorang murid Kristus, yang mengasihi dan mengikut Kristus serta hidup sesuai karakter Tuhan Yesus dengan sepenuh hati. Ini merupakan artikel kajian literatur yang menggunakan metode deskriptif. Kajian deskriptif diterapkan pada gembala-gembala sidang GPdI se-Kabupaten Jember yang berjumlah 28 orang sebagai partisipan. Data-data penelitian diperoleh secara langsung dari lapangan dengan menggunakan instrument penelitian dalam bentuk angket. Setelah dilakukan analisis untuk mendapatkan jawaban berdasarkan prosentasi skor partisipan, maka dapat disimpulkan bahwa nilai implementasi pola pemuridan Yesus menurut Injil Matius dikalangan Gembala Sidang GPdI se-kabupaten Jember adalah sangat tinggi, yaitu 90,30\%.
\end{abstract}

Kata kunci: gembala sidang; melayani; pemuridan; pola pemuridan

\section{PENDAHULUAN}

Tuhan Yesus adalah pemurid sejati. Satu-satunya teladan pemuridan terbaik bagi gereja adalah pola pemuridan yang dilakukan Tuhan Yesus sang Guru Agung. Pada zaman Yesus, istilah murid biasa dipakai untuk menunjuk kepada orang-orang yang mengikuti dan belajar dari gurunya. Matius 11:27; 14:12, Markus 2:18 menjelaskan ada orang yang mengikuti 
Yohanes Pembaptis disebut murid-murid Yohanes Pembaptis, ada yang mengikuti orang Farisi disebut murid-murid orang Farisi dan ada yang mengikut Yesus disebut murid-murid Yesus.

Menarik melihat inti Injil Matius, di mana ia tidak menekankan tentang pemahaman "rasul" (utusan) pada murid-murid Yesus dalam tulisannya, karena inti Injil Matius adalah pada istilah "murid." Matius berhadapan dengan orang Yahudi yang khas dengan pemuridannya, pasti menganggap penting akar istilah "murid" tersebut. Yaitu seorang yang belajar. Murid belajar secara langsung kepada sang Gurunya. Proses pembelajaran yang paling banyak dilakukan oleh guru kepada muridnya pada masa itu adalah simurid mengikuti gurunya kemanapun ia pergi dan menerapkan setiap ajarannya. Pola ini juga yang dilakukan oleh Tuhan Yesus dalam pola pemuridanNya. Hal ini seperti yang dijelaskan oleh Bartlett selanjutnya bahwa pemuridan Yesus tak muncul atas dasar suatu penggabungan bebas pada seorang pengajar, namun atas dasar suatu panggilan untuk mengikutinya yang datang dari Yesus. ${ }^{2}$

Penulis Injil Matius tidaklah diketahui dengan pasti, karena kitab itu tidak menjelaskan secara terang siapa penulisnya. Tetapi kesaksian bapa-bapa gereja yang mula-mula menyatakan bahwa Injil ini ditulis oleh Matius, salah seorang murid Yesus (Mat. 9:9-13; 10:3). Eusebius ( \pm tahun 325) mengutip Papias ( \pm tahun 100) mengatakan bahwa Matius telah menyusun ajaran Tuhan dalam bahasa Aram yang kemudian diterjemahkan kedalam bahasa Yuhani. ${ }^{3}$ M. E. Duyverman melihat dari sisi lain dan menduga Injil Matius bukan Matius murid Yesus sebagai penulisnya. ${ }^{4}$ Alasannya, menurut anggapan para ahli, Injil Matius yang kita kenal sekarang bukanlah terjemahan, melainkan karangan Yuhani asli.

Selain itu, Matius adalah murid Yesus yang menjadi saksi mata semua peristiwa yang dilakukan oleh Yesus, jadi untuk apa dia menulis dengan mengambil bahan dari sumber lain. B.F. Drewes mengatakan: "mungkin sekali buku ini disusun oleh seorang Kristen Yahudi bagi jemaat yang sebagian besr terdiri orang Kristen Yahudi pula." ${ }^{\text {, Mengetahui }}$ siapa penulis Injil ini dengan pasti, bukanlah tujuan dari penelitian ini, jadi bagi penulis sendiri tetap menyatakan bahwa Matius murid Yesuslah yang menulis kitab injil Matius. Dalam bukunya, Paul Enns menjelaskan bahwa: pandangan gereja mula-mula adalah bahwa "Matius menulis Injilnya sebelum penginjil lain menyusun kepunyaan mereka. Kesaksian ini sangat kuat dan tak bernama yang hal itu mengharuskan kepemilikan cukup besar dalam memutuskan pertanyaan ini. Matius paling mungkin ditulis kira-kira tahun 50 AD. ${ }^{6}$ Dalam

\footnotetext{
${ }^{1}$ David L. Bartlett, Pelayanan Dalam Perjanjian Baru (Jakarta: BPK Gunung Mulia, 2000), 82

${ }^{2}$ Ibid, 83

${ }^{3}$ Meril C. Tenney, Survey Perjanjian Baru (Malang: Gandum Mas, 2000), 183

${ }^{4}$ M. E. Duyverman, Pembimbing ke dalam Perjanjian Baru (Jakarta: BPK Gunung Mulia, 2011), 48.

${ }^{5}$ B. F. Drewes, Satu Injil Tiga Pekabar (Jakarta: BPK Gunung Mulia, 2009), 175.

${ }^{6}$ Paul Enns, The Moody Handbook of Theology (Malang: Literatur SAAT, 2008), 97.
} 
buku perkembangan Teologi Misi, Kanti Widiastuti menyatakan bahwa paradigm Matius adalah pemuridan missioner. $^{7}$

Pengertian murid secara etimologi berasal dari kata Ibrani: (limmud) dan kata Yunani: (manthano), artinya: seorang yang belajar. Selanjutnya kata manthano berkembang menjadi: (Mathetes) artinya adalah murid. ${ }^{8}$ Ensiklopedia Alkitab Masa Kini menjelaskan tentang kata murid sebagai berikut: diluar kitab Injil, kata itu hanya terdapat dalam Kis dengan arti orang-orang percaya, yang mengaku Yesus sebagai Mesias 6:1,2,7; 9:36 (bentuk per mathetria); 11:26. Bentuk kata kerja Matheteuo, artinya, "menjadi murid", menjadi seorang lain menjadi murid, terdapat dalam matius 27:57; 28:19. ${ }^{9}$

Pada zaman Perjanjian Baru, Matius lebih banyak menjelaskan tentang murid dari pada kitab-kitab lainnya, dan hal itu selalu menujuk kepada dua belas orang murid Tuhan Yesus. Dalam kamus Alkitab yang dikarang oleh W.R.F. Browning, kata murid-murid berarti:

Pengikut-pengikut setia seorang guru.. dan kata-kata ini juga dikenakan kepada orangorang yang menyertai Yesus (Mrk. 6:45), diantaranya adalah ketujuh puluh murid (Luk. 10:1,23), dan yang hubungannya paling dekat adalah kedua belas murid (Mat. 10:1). Dalam Matius ridak hanya belajar dari Yesus, tetapi juga mengajar (28:20), bahkan mengampuni dosa (18:18). ${ }^{10}$

Defenisi pemuridan yang mencangkup baik penginjilan maupun pembinaan dijelaskan oleh Ronald W. Leigh sebagai berikut:

Pemuridan adalah suatu proses sengaja dimana seorang Kristen yang lebih dewasa berhubungan dengan satu atau ebih orang secara sengaja dan pribadi dalam suatu periode waktu yang panjang, membimbing pengalaman-pengalaman mereka sehingga pada akhirnya mereka berkembang menjadi orang Kristen yang dewasa dan mampu melakukan hal yang sama dengan lainnya. ${ }^{11}$

Bila dihubungkan dengan pemuridan Tuhan Yesus, tentu sudah seharusnya, seorang pelayan adalah seorang murid Kristus, yang mengasihi dan mengikut Kristus sertya hidup sesuai dengan karakter Tuhan Yesus dengan sepenuh hati. Seorang murid pasti akan menghasilkan murid lainnya. Itulah sebabnya, seorang Gembala sidang perlu memuridkan para pelayan digerejanya, supaya pemuridan akan menghasilkan murid-murid yang

\footnotetext{
${ }^{7}$ Kanti Widiastuti, Perkembangan Teologi Misi (Semarang: Sekolah Tinggi Theologia Baptis Indonesia, 2006), 22.

${ }^{8}$ Harold K. Moulton, ed., The Analytical Greek Lexicon Revised, (Grand Rapids: Zondervan Publishing House), 257.

9 J. D. Douglas, Ensiklopedia Alkitab Masa Kini, Vol. 2, (Jakarta: Yayasan Komunikasi Bina Kasih, 1997), 100 .

${ }^{10}$ W. R. F. Browning, Kamus Alkitab, Panduan Dasar ke Dalam Kitab-Kitab, Tema, Tempat, Tokoh dan Istilah Alkitabiah (Jakarta: BPK Gunung Mulia, 2009).

${ }^{11}$ Ronald W. Leigh, Melayani Dengan Efektiif (Jakarta: Gunung Mulia, 2007), 128-129.
} 
membuat gereja sehat dan mengalami pertumbuhan dengan pelipatgandakan. Wagner menjelaskan tentang usaha gembala dalam pertumbuhan gereja adalah: "Pertumbuhan gereja meliputi segala sesuatu yang ada sangkut-pautnya dalam usaha membawa orangorang yang tidak mempunyai hubungan pribadi dengan Yesus Kristus kepada persekutuan dengan-nya dan kepada keanggotaan gereja yang bertanggungjawab.","2

\section{BAHAN DAN METODE}

\section{Pola pemuridan Yesus menurut Injil Matius}

Pemaparan pola pemuridan Yesus menurut Injil Matius adalah prinsip-prinsip yang dapat digali dari beberapa ayat dalam Injiul Matius yang diinterpretasikan sebagai pemuridan yang dilakukan oleh Tuhan Yesus. Ada empat interpretasi ayat yang akan menjadi indicator penelitian ini, yaitu: 1) Pemilihan murid (Mat. 4:19-20; 10:1-4), Pembetukan murid (Mat. 16:24), Pengawasan murid (Mat. 10:5-15) dan Penutusan murid (Mat. 28:18-20).

\section{Pemilihan Murid (Mat. 4:19-20; 9:9; 10:-4)}

Dalam proses pemanggilan dan pemilihan orang-orang yang akan dijadikan murid oleh Yesus, Matius menuliskan beberapa peristiwa penting: Pertama, Yesus memanggil beberapa orang nelayan. Yesus berkata kepada mereka:"Mari, ikutlah Aku, dan kamu akan kujadikan penjala manusia. "Lalu merekapun segera meninggalkan jalanya dan mengikut dia. (Mat. 4:19-20). Kedua, Yesus juga memanggil Matius, pemungut cukai. " Setelah Yesus pergi dari, Ia melihat seorang yang bernama Matius duduk dirumah cukai, lalu ia berkata kepadanya: "Ikutlah Aku." Maka berdirilah Matius lalu mengikut Dia." (Mat. 9:9).

Dalam menjaring calon murid, Yesus mengadakan pendekatan pribadi kepada mereka. Untuk mengambil seorang murid, Yesus tidak melalui perantara. Yesus langsung mengajak calon murid itu untuk mengikuti-Nya. Yesus mengatakan, "Mari Ikutlah Aku!" Kepada simon dan Andreas (Mat. 4:19), dan Yakobus dan Yohanes (Mat. 4:22). Kalimat: "Mari Ikutlah Aku" dalam bahasa yunani Deute hopiso mou. Kalimat itu mempunyai pengertian: perintah untuk datang dan ikut berjalan di belakang Yesus . dalam Matius 4:19, Yesus berkata "Aku akan menjadikan kamu penjala manusia!" Warren W. Wiersb menjelaskan bahwa "penjala manusia" bukanlah istilah baru. Selama berabad-abad, para filsuf Yunani dan Romawi telah menggunanakannya untuk menggambarkan seseorang yang berusaha "menangkap" orang lain dengan mengajar dan memengaruhi."13 Pendekatan ini langsung mendapat tanggapan yang baik dari calon murid. Matius mencatat respon Simon dan Andreas: "Lalu merekapun segera meninggalkan jalanya mengikuti Dia" (Mat. 4:20)., dan

\footnotetext{
${ }^{12}$ C. Peter Wagner, Strategi Pertumbuhan Gereja (Malang: Gandum Mas, 1990), 100.

${ }^{13}$ Warren W. Wiersb, Seri Tafsiran Matius:Loyal di Dalam Kristus Mengikuti Raja Segala Raja (Bandung: Kalam Hidup, 2012), 42.
} 
respon Yakobus dan Yohanes: "dan mereka segera meninggalkan perahu serta ayahnya, lalu mengikuti Dia” (Mat. 4:22)

Berbeda dengan pemanggilan pertama, kepada Matius Yesus juga berkata: "Ikutlah Aku" (Mat. 9:9). Tetapi, kata: "Ikutlah", dalam bahasa yunani dari kata yang berbeda, yaitu: (akolouthei). ${ }^{14}$ Kata ini adalah: Verb imperative present active $2^{\text {nd }}$ person singular

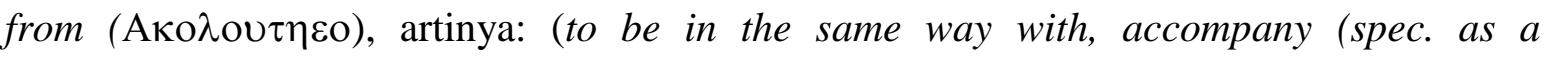
disciple)). ${ }^{15}$ Yesus memanggil Matius dengan panggilan yang lebih tegas, yaitu menjadi seorang murid yang akan mengikuti gurunya kemanapun gurunya pergi. Mengapa cara Tuhan Yesus memanggil Matius berbeda? Brian Byrne mengatakan alasannya adalah " di beberapa daerah dari lingkungan masyarakat yahudi, Matius dianggap penjahat. Ia tidak disukai, dibenci, diakui, dan menjadi kayak arena tidak ada batasan untuk keserakahannya...menurut orang Yahudi seperti Matius hampir mustahil bisa bertobat. "ketika Yesus masuk kedalam kehidupan Matius, Yesus ingin merevolusi dan merevormasi Matius, masuk kedalam pertobatan dan menjadi seorang murid yang radikal kepada Tuhan Yesus, dengan tidak lagi memikirkan apapun yang sudah menjadi masa lalunya.

Tentu, Matius mengetahui konsekuensi meninggalkan pekerjaan sebagai pemungut cukai akan sangat merugikan, baik masalah kedudukan, kehilangan mata penceharian, dicap sebagai "Orang berdosa" oleh orang-orang yahudi, dan yang lainnya. Tetapi, ternyata pendekatan pribadi Yesus membuat Matius langsung meninggalkan meja pajaknya Dan mengikut Yesus.

\section{Pembetukan Murid (Mat. 16:24)}

"Lalu Yesus berkata kepada murid-muridnya: "Setiap orang yang mengikut Aku, dia harus menyangkal dirinya, memikul salibnya dan mengikut Aku." Frasa "Penyangkalan diri" dalam bahasa Yunani dituliskan (Aparneomai), yang artinya: 1) to deny 1a) to affirm that one has no acquaintance or connection with someone $1 \mathrm{~b}$ ) to forgrt one's self, lose sight of one's own interests. ${ }^{17}$ Penyangkalan diri berarti: meluoakan dirinya sendiri atau kehilangan segala sesuatu dari dirinya demi mengikuti Kristus. Inio adalah cara persekutuan terbaik dengan Tuhan Yesus, yaitu kehilangan diri sendiri untuk menjadi serupa dengan Tuhan Yesus Kristus.

Penyangkalan diri membawa persekutuan murid-murid kepada Yesus. Air tersebut diatas merupakan hakikat menjadi murid Yesus. Menjadi muridNya tidak hanya sebatas

\footnotetext{
${ }^{14}$ Bible Work 8

15 James Strong, Strong's Exhaustive Concordance of the Bible, Greek Dictionary of the New Testament I (USA: World Bible Publisher), 8.

${ }^{16}$ Brian Byrne, Be My Disciple, Karakter Sejati Seorang Murid Kristus Abad-21 (Yogyakarta: ANDI

${ }^{17}$ Bible Work 8
} Offset, 2010), 73. 
mengenal Yesus tetapi juga mengikut jejakNya. Ia mau supaya murid-muridNya hidup seperti hidupNya. Yesus menghendaki murid-muridNya untuk menanggalkan diri lama, kita yang telah dikuasai oleh dosa lalu mengikut gaya hidup Yesus sepenuhnya, seperti Yesus perna bersabda, "Karena itu haruslah kamu sempurna, sama seperti bapamu di sorga adalah sempurna"( Mat. 5:48)

Seperti yang telah jabarkan, kata "murid" mengandung dimensi yang lebih luas dari sekedar pemahaman. Pengertian "murid" pada waktu itu mencangkup juga gaya hidup seseorang yang mengikuti apa yang di pelajari sehingga itu menjadi cirri khasnya. Tuhan Yesus membetuk murudNyalewat persekutuan. System pemuridan Yesus kepada kedua belas muridnya lebih kepada membangun hubungan dari pada kurikulum formal sekolah. Menurut penelitian yang terus menerus dengan Yesus menjadi sebuah metode pembentukan karakter murid-murid yang paling efektif. Sehingga murid-murid Tuhan Yesus,pada akhirnya menjadi orang-orang yang melakukan apa yang Yesus ajarkan dan mengajarkan kepada orang lain apa yang Yesus ajarkan. Menurut peneliti inilah proses pemuridan yang sejati.

Frasa "memikul salib" menurut peneliti mengarah kepada pelatihan murid. Tuhan Yesus melatih murid-murid untuk dapat melayani secara efektif dan tahan menderita ditengah aniaya. Menjadi murid Yesus bukanlah melakukan sebuah perjalanan Rohani yang mulus. Akan ada tantangan dan aniaya yang menghadang di depan. Itulah sebabnya, Yesus melatih murid-murid-Nya. Setiap hari Yesus menyampaikan pengajaran-Nya, dan melatih para murid untuk melakukan yang dipertahankanNya kepada mereka. Pendekatan secara pribadi tersebut ternya efektif dan akhirnya melahirkan pemimpin-pemimpin gereja yang luar biasa.

Dimana pun juga Tuhan Yesus mengijinkan murid-murid itu masuk kedalam hidupNya. Begitulah prosesnya sehingga mereka menjadi seperti itu. Mereka tidak hanya sekelompok siswa yang duduk dan membahas seluk beluk dari apa yang sedang Ia ajarkan. Tuhan Yesus memang mengajar, namun ajaran itu selalu merupakan sebuah pengalaman belajar terpadu dimana murud-murid-Nya akan mengetahuinya dan menyerapkan. Mengetahuinya dan menerapkan, seringkali pada hari yang sama. Tuhan Yesus memberikan teladan bagi muridNya bahwa pemuridan ialah mengaitkan kepercayaan dengan perilaku.

Kata “ Mengikut Aku” pada ayat diatas mengacu kepada penyerangan diri murid-murid kepada Tuhan Yesus. Tuhan Yesus menghendaki ketaatan sepenuhnya dari pengikutpengikutNya. Ketaatan itu harus sampai pada akhir hidup murid-murid. Contoh penyertaan Yesus tentang penyerahan diri murid-murid ada di Matius 8:21-22 "seorang lain, yaitu salah seorang muridNya, berkata kepadaNya: "Tuhan, izinkanlah aku pergi dahulu menguburkan ayahku.tetapi Yesus berkata kepadanya: "Ikutlah Aku dan biarlah orangorang mati mengububurkan orang-orang mati mereka." 
Yesus sangat tegas kepada murid-muridNya yang meminat kepadaNya untuk pergi ke rumahnya untuk menguburkan ayahnya. Yesus berkata: "Ikutlah Aku, biar orang mati menguburkan oaring mati." Dari perkataan Yesus tersebut, peneliti simpulkan bahwa panyerahan diri merupakan harga mati untuk menjadi seorang murid Yesus. Sama halnya dengan apa yang dikatakan oleh William MacDonald: "Yesus tidak mencari pria dan wanita yang memberikan sebagai malam kepadaNya atau akhir pekan mereka atau masa pension mereka. Ia mencari orang yang mendapat memberikan kepadaNya tempat pertama didalam hidup mereka."18

Setiap hari Yesus menyampaikan pengajaranNya, dan melati para murid untuk melakukan yang di perintahkanNya kepada mereka. Pendekatan secara pribadi tersebut ternyata efektif dan akhirnya melahirkan pemimpin-pemimpin gereja yang luar biasa.

\section{Pengawasan Murid (Mat. 10:5-15)}

Dalam memuridkan murid-muridNya, Tuhan Yesus tidak hanya sekedar melepaskan mereka untuk melayani. Tuhan mengadakan pengawasan kepada mereka. Dalam Matius 10:5-15, Tuhan Yesus menutus murid-muridNya. Setiap kali murid-murid menyelesaikan tugas pemberitaan injil, Tuhan Yesus mendekati mereka untuk mendengarkan laporanlaporan kerja mereka dan juga membagikan pengalaman-pengalamannya dalam hal-hal yang sama (Luk. 10:17-20). Robert E. Coleman menjelaskan: Dalam perhimpunan para murid, pengalaman-pengalaman mereka diperiksa setelah mereka kembali dari kunjungankunjungan mereka. Di situ kita melihat dengan jelas strategi Tuhan Yesus dalam seluruh pelayanan-Nya. Apabila Ia meninjau kembali pengalaman murid-murid-Nya, Ia juga menunjukkan kepada mereka cara yang praktis untuk menerapkannya dalam kehidupan mereka. $^{19}$

Tuhan Yesus ingin murid-muird menyampaikan Firman Allah dengan mencontoh apa yang telah Yesus lakukan dan bagaimana Ia telah melakukan-Nya. Lois E. Lebar menjelaskan pola-pola itu berada, dan membiarkan tanggapan dan kesiapan murid itu membimbing proses, catatan Injil penuh dengan perkataan-perkataan dan perbuatanperbuatan orang-orang lain, sama seperti perkataan-perkataan dan perbuatan-Nya sendiri. ${ }^{20}$ Jadi murid-murid ketika masuk ke dalam salah satu kota-kota Israel, mereka memberi salam, lalu masuk ke salah satu rumah untuk memberitakan kerajaan Allah disana. Mereka akan mengajar di rumah itu seperti gaya hidup orang-orang Yahudi sehari-hari. Itulah yang

\footnotetext{
${ }^{18}$ William Mac Donald, Pemuridan Sejati (Surabaya: KDP, 2009), 9.

${ }^{19}$ Robert E. Coleman, Rencana Agung Penginjilan (Bandung: Kalam Hidup, 1964), 70.

${ }^{20}$ Lois E. Lebar, Education That Is Christian: Proses Belajar Mengajar Kristiani \& Kurikulum yang Alkitabiah (Malang: Gandum Mas, 2006), 112.
} 
Lebar maksudkan bahwa latar belakang pengajaran Yesus tampak jelas baik dari teks itu sendiri atau dari kebiasaan-kebiasaan orang-orang Yahudi. ${ }^{21}$

Tuhan Yesus, ketika menyuruh murid-murid melayani, Ia ingin supaya murid-murid menggali potensi dan karakter diri mereka untuk menjadi yang lebih baik lagi. Stephen Tong berkata: "Seorang yang hanya bisa melihat keluar dan tidak menggali diri sendiri, tidak akan pernah menjadi satu karakter yang agung." ${ }^{22}$ Orang-orang itulah yang akan melaksanakan amanat Agung Tuhan Yesus. Untuk masuk area pelayanan tersebut, George Barna berkata: "Anda harus mengenali berbagai nilai, prilaku, asumsi, dan pengalaman yang mendasari pelayanan anda.",23

Dalam pelayanan, Tuhan Yesus ingin supaya murid-murid tetap mengikuti aturan main-Nya. William MacDonald berkata: Aturan dasarnya adalah bahwa para pengikut Yesus seharusnya memperlakukan orang lain sebagaimana mereka ingin diperlakukan. Hal ini berarti bahwa mereka seharusnya bersikap sopan santun, sabar, murah hati, tidak berpusat kepada diri sendiri, bersifat tidak memihak, mudah memberikan maaf, suka menolong dan masih banyak sifat yang lain. ${ }^{24}$ Jadi pelayanan pemberitaan Injil, walaupun berhubungan dengan hal-hal rohani dan hidup yang kekal, tetapi Tuhan Yesus juga tetap konsisten bahwa hal-hal yang bersifat moral dan etika akan sangat mempengaruhi berhasil atau tidaknya sebuah penginjilan.

Pengutusan Murid (Matius 28:18-20)

"Karena itu pergilah, jadikanlah semua bangsa murid-Ku dan baptislah mereka dalam nama Bapa dan Anak dan Roh Kudus, dan ajarlah mereka melakukan segala sesuatu yang telah Kuperintahkan kepadamu. Dan ketahuilah, Aku menyertai kamu senantiasa sampai kepada akhir zaman." Dari ayat di atas, peneliti melihat kepada dua hal, yaitu pengutusan untuk memuridkan bangsa-bangsa dan penyertaan Tuhan Yesus. Peneliti akan fokus membahas ayat ini dengan mengeksegesa beberapa kata penting, yaitu "pergilah

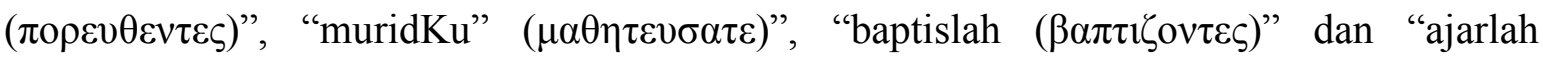
$(\delta 1 \delta \alpha \sigma \kappa о \nu \tau \varepsilon \zeta) "$.

Dalam terjemahan bahasa Indonesia, keempat kata ini sepertinya merupakan kata perintah dan dapat berdiri sendiri. Tetapi bila melihat dari bahasa Yunani, akan terlihat jelas

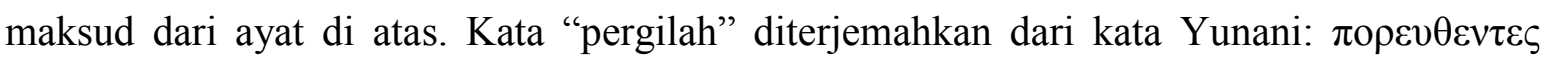
(poreuthentes, ) kasusnya: partisip aorist deponent, nominatif maskulin, orang kedua jamak,

\footnotetext{
${ }^{21}$ Ibid., 113.

${ }^{22}$ Mary Setiawani \& Stephen Tong, Seni Membentuk Karakter Kristen: Hikmat Guru dan Ayah Bunda (Jakarta: Lembaga Reformed Injili Indonesia, 1995), 99.

${ }^{23}$ George Barna, The Power of Vision: Tanpa Visi Gereja Hancur (Malang: Gandum Mas, 2009), 75.

${ }^{24}$ William MacDonald, Ikutilah Yesus! Pedoman Bagi Murid-murid Yesus (Sastra Hidup Indonesia, 2012), 27.
} 
dari kata poreuomai. Kata "murid" diterjemahkan dari kata Yunani: $\mu \alpha \theta \eta \tau \varepsilon v \sigma \alpha \tau \varepsilon$ (matheteusate), kasusnya: imperatif aorist aktif, orang kedua jamak, dari kata matheteuo. Kata "baptislah" diterjemahkan dari kata Yunani: $\beta \alpha \pi \tau \imath \zeta o v \tau \varepsilon \varsigma$ (baptizontes,) kasusnya: partisip present aktif nominatif maskulin, orang kedua jamak dari kata: baptizo. Kata "ajarlah" diterjemahkan dari kata Yunani: $\delta 1 \delta \alpha \sigma \kappa o v \tau \varepsilon \varsigma$ (didaskontes), kasusnya: partisip present aktif nominatif maskulin, orang kedua jamak, dari kata: didasko.

Kasus dari kata-kata di atas dapat dijelaskan sebagai berikut: Dalam tata bahasa Yunani, bentuk partisip berfungsi sebagai verbal adjectives. Unsur-unsur ini merupakan gabungan antara unsur-unsur yang terdapat dalam sebuah kata kerja dan kata sifat dalam bahasa Yunani. Dalam fungsi sebagai verbal, sebuah kata berbentuk partisip "bertugas" untuk menjelaskan tentang kata kerja utama di dalam sebuah kalimat. Dalam fungsi sebagai adjective, sebuah kata berbentuk partisip "bertugas" menjelaskan tentang kata benda utama di dalam sebuah kalimat. Jadi, dapat katakan bahwa kata pergilah, baptislah dan ajarkanlah bukanlah kata kerja utama, tetapi kata kerja yang akan menjelaskan kata kerja utama. Kata kerja utama dalam ayat diatas adalah: jadikan murid.

Berarti, perintah pergilah, baptislah dan ajarkanlah, semuanya pendukung supaya orang tersebut menjadi murid. Dalam hal ini dapat disimpulkan bahwa perintah utama dalam Amanat Agung adalah menjadikan murid.kan menjelaskan kata kerja utama. Kata kerja utama dalam ayat di atas adalah: jadikan murid. Untuk menjadikan murid, murid-murid harus pergi (memberitakan Injil), LeRoy Eims berkata: "Kita meneguhkan penyerahan kita bagi Amanat Agung Tuhan kita dan menyatakan kesediaan untuk pergi kemanapun, melakukan apapun dan mengorbankan apapun yang diperlukan Allah dari kita dalam pemenuhan tugas itu.",25

Peneliti menyimpulkan bahwa pengutusan murid-murid ke seluruh dunia tidak terbatas hanya pada misi penginjilan saja, bukan pula hanya membaptis para petobat baru saja, bukan hanya mengajarkan ajaran-ajaran Yesus saja, tetapi pengutusan itu mencakup keseluruhan, yaitu pergi, baptis, ajarkan dan muridkan. Terdorong oleh amanat Yesus itu, maka seharusnya murid-murid bukan hanya sekedar mengikut Yesus, tetapi membawa orang-orang lain juga untuk mengikut Tuhan Yesus. Itulah hukum pelipatgandaan, yaitu dimuridkan untuk memuridkan. Bila dilakukan perbandingan perhitungan antara pertambahan jemaat dan pelipatgandaan murid, dengan kelipatan tetap, dihitung selama lima belas tahun, maka hasilnya akan terlihat seperti tabel 2 berikut:

\footnotetext{
${ }^{25}$ LeRoy Eims, Penuai Yang Diperlengkapi (Malang: Gandum Mas, 1988), 10.
} 


\begin{tabular}{|c|c|c|}
\hline \multicolumn{3}{|c|}{ Pertambahan jemaat VS Pelipatgandaan murid } \\
\hline \multirow{2}{*}{ Tahun } & $\begin{array}{c}\text { Pertambahan jemaat } \\
100 \text { orang/Tahun }\end{array}$ & $\begin{array}{c}\text { Pelipatgandaan murid } \\
\text { orang/Tahun }\end{array}$ \\
\hline 1 & 100 & 2 \\
\hline 2 & 200 & 4 \\
\hline 3 & 300 & 8 \\
\hline 4 & 400 & 16 \\
\hline 5 & 500 & 32 \\
\hline 6 & 600 & 64 \\
\hline 7 & 700 & 128 \\
\hline 8 & 800 & 256 \\
\hline 9 & 900 & 512 \\
\hline 10 & 1.000 & 1.024 \\
\hline 11 & 1.100 & 2.048 \\
\hline 12 & 1.200 & 4.096 \\
\hline 13 & 1.300 & 8.192 \\
\hline 14 & 1.400 & 16.384 \\
\hline 15 & 1.500 & 32.768 \\
\hline Dan seterusnya $\ldots$ & & \\
\hline & & \\
\hline
\end{tabular}

Bila dicermati, maka akan terlihat jelas perbedaan hasil antara pertambahan dengan pelipatgandaan. Pada tahun-tahun pertama, pertambahan terasa jauh lebih cepat daripada pelipatgandaan. Tetapi semakin meningkat tahunnya akan terlihat keunggulan jumlah pelipatgandaan. Pada tahun ke lima belas, perbandingan jumlah pertambahan murid dengan pelipatgandaan murid adalah: 1.500:32.768, suatu perbedaan yang sangat signifikan.

Apa yang dapat diketahui dari data ini? Pertama, Yesus tidak salah ketika Dia berkata kepada murid-murid-Nya bahwa luas daerah kerja mereka adalah seluruh dunia. Yesus tahu bahwa dengan hukum pelipatgandaan, murid akan menghasilkan murid yang berlipat ganda, sehingga memberitakan Injil kepada segala bangsa bukanlah sesuatu yang tidak mungkin. Kedua, Proses pelipatgandaan murid sepertinya makan waktu yang sangat lama untuk dapat menuai dan melihat hasil. Orang pada umumnya lebih tertarik melihat hasil daripada mengikuti prosesnya. Tetapi orang yang setia pada hukum pelipatgandaan, akan menuai hasil yang luar biasa dalam pelayanannya.

Kata "bangsa" pada ayat di atas diterjemahkan dari kata (ethne), yang dalam bahasa Indonesia identik dengan kata "etnik/etnis." Kata etnik, dalam bahasa Kamus Besar Bahasa Indonesia artinya: bertalian dengan kelompok sosial dalam sistem sosial atau kebudayaan. ${ }^{26}$ Kelompok sosial dalam masyarakat dapat juga dinyatakan "suku" atau kelompok-kelompok sosial lainnya. Jadi, pengutusan murid harus dapat masuk kepada semua segi kehidupan

\footnotetext{
${ }^{26}$ Kamus Besar Bahasa Indonesia, (Jakarta: Balai Pustaka, 1996), 271.
} 
dalam masyarakat, memberitakan injil di sana, menjadi berkat serta membawa pengaruh Kristus.

Adapun langkah kerja penelitian yang digunakan dalam penelitian ini adalah metode kualitatif dengan pendekatan deskriptif. ${ }^{27}$ Penelitian kualitatif dalam hal ini lebih menekankan sikap penelitian yang bermuatan nilai dan mencari jawaban atas pertanyaanpertanyaan yang menekankan bagaimana pengalaman sosial diciptakan dan diberi makna. ${ }^{28}$ Data-data penelitian diperoleh secara langsung di lapangan dengan menggunakan instrumen penelitian dalam bentuk angket. Instrumen-instrumen angket dibuat dengan model pernyataan-pernyataan yang disusun berdasarkan indikator-indikator yang telah dijelaskan di bab 2. Pernyataan-pernyataan tersebut kemudian diberikan jawaban "ya" atau "tidak". Selanjutnya jawaban tersebut akan diolah secara deskriptif untuk menjawab pertanyaan penelitian.

\section{Teknik pengumpulan data}

Peneliti menggunakan metode pengumpulan data dengan menggunakan angket. Prosedur pengumpulan data yang akan dilakukan peneliti adalah menyebarkan angket kepada gembala-gembala GPdI se-Kabupaten Jember, lalu mengumpulkannya dengan mendatangi masing-masing gembala sidang GPdI di rumahnya. Kisi-kisi instrumen di atas kemudian dikonsultasikan kepada dosen pembimbing untuk mendapatkan validasi. Kisikisi yang telah divalidasi akan dilampirkan di lampiran. Setelah kisi-kisi divalidasi, dibuat angket untuk disebarkan kepada gembala-gembala sidang GPdI se-Kabupaten Jember.

\begin{tabular}{|c|c|c|c|}
\hline Variabel & Indikator & Sub Indikator & Pertanyaan \\
\hline \multirow{6}{*}{$\begin{array}{l}\text { Pola Pemuridan } \\
\text { Yesus }\end{array}$} & \multirow[t]{4}{*}{$\begin{array}{l}\text { Pemilihan } \\
\text { Murid }\end{array}$} & Pendekatan pribadi & $\begin{array}{l}\text { Saya mengadakan pendekatan pribadi kepada } \\
\text { jemaat sebelum saya memilih mereka menjadi } \\
\text { murid. }\end{array}$ \\
\hline & & Selektif dalam memilih & $\begin{array}{l}\text { Saya mengadakan seleksi untuk memilih } \\
\text { jemaat yang akan dijadikan murid. }\end{array}$ \\
\hline & & $\begin{array}{l}\text { Berdoa sebelum } \\
\text { memilih. }\end{array}$ & $\begin{array}{l}\text { Saya akan berdoa dengan bergumul terlebih } \\
\text { dahulu sebelum saya memilih murid. }\end{array}$ \\
\hline & & $\begin{array}{l}\text { Memilih dari ragam } \\
\text { kepribadian }\end{array}$ & $\begin{array}{l}\text { Saya memilih calon murid dari beragam } \\
\text { kepribadian, sesuai dengan seleksi yang telah } \\
\text { saya buat. }\end{array}$ \\
\hline & \multirow[t]{2}{*}{$\begin{array}{l}\text { Pembentuka } \\
\text { n Murid }\end{array}$} & Persekutuan & $\begin{array}{l}\text { Saya akan membentuk murid-murid melalui } \\
\text { persekutuan pemuridan di gereja. }\end{array}$ \\
\hline & & Pelatihan & $\begin{array}{l}\text { Saya akan membentuk murid-murid melalui } \\
\text { pelatihan-pelatihan yang disusun secara } \\
\text { berkala. }\end{array}$ \\
\hline
\end{tabular}

${ }^{27}$ Arif Furchan, Pengantar Metode Penelitian Kualitatif (Surabaya: Usaha Nasional Indonesia, 1992),

22.

${ }^{28}$ Conny R. Semiawan, Metode Penelitian Kualitatif (Jakarta: Grasindo, 2007), 60. 


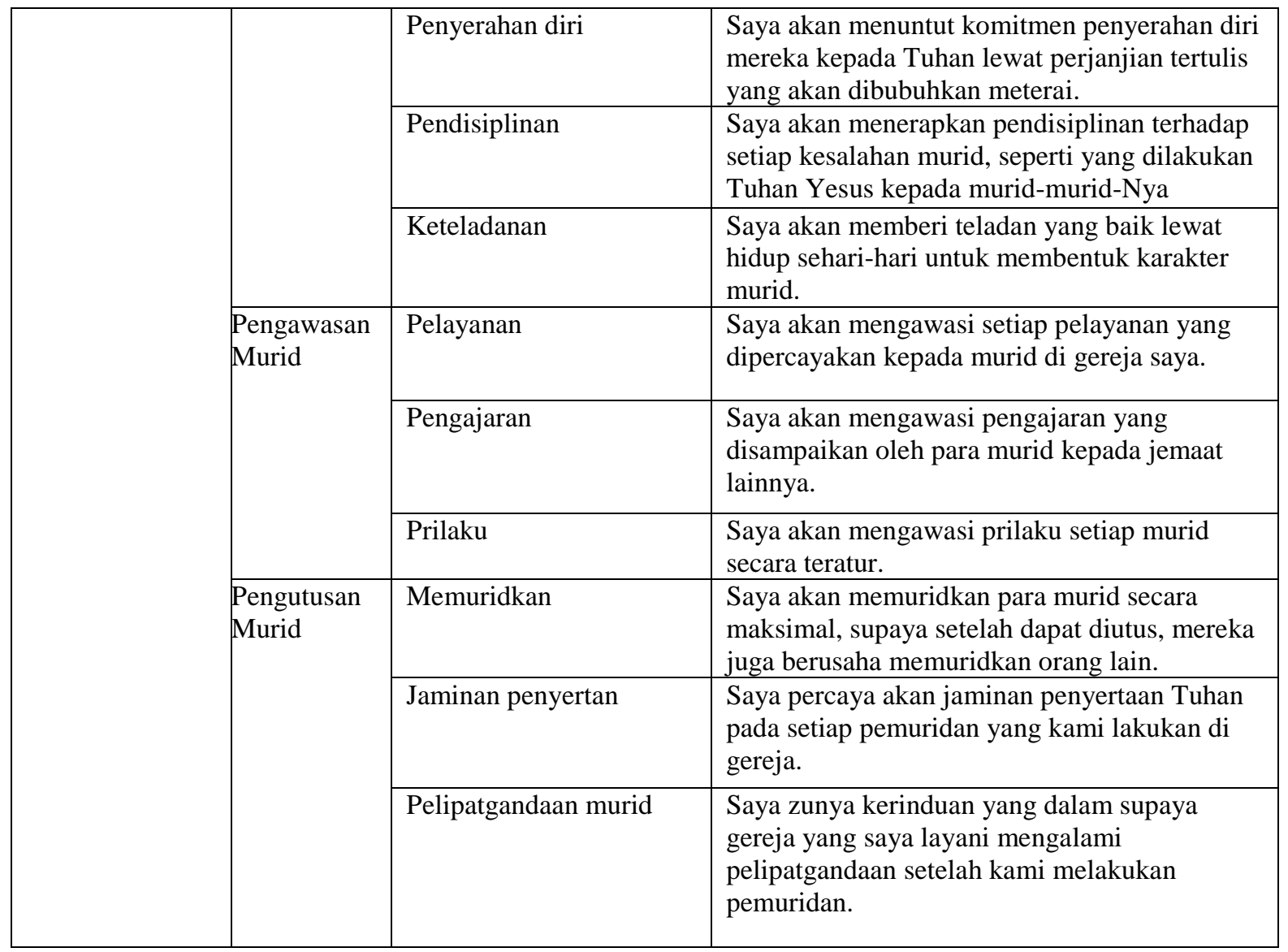

Dari kisi-kisi instrumen ini dibuat angket dengan 26 pernyataan untuk disebarkan kepada gembala-gembala sidang GPdI se-Kabupaten Jember. Jawaban angket yang akan disebar menggunakan Skala Guttman, yaitu: skala pengukuran untuk mendapatkan jawaban yang tegas, yaitu "ya-tidak". ${ }^{29}$ Selanjutnya menurut Guttman, jawaban dapat dibuat dalam bentuk pilihan ganda, juga dapat dibuat dalam bentuk checklist. Jawaban dapat dibuat skor tertinggi satu (1) dan terendah nol (0). Analisa dilakukan seperti skala Likert. ${ }^{30}$

\section{HASIL DAN PEMBAHASAN}

Langkah-langkah analisis data dari hasil angket yang telah disebarkan kepada gembalagembala siding-GPdI se Kabupaten Jember adalah sebagai berikut: Data angket yang sudah dikumpulkan didiskripsikan dalam bentuk tabel. Jawaban "Ya" akan diberi skor 1 dan "Tidak" akan diberi skor 0. Hasilnya sebagai berikut: Proses analisis terhadap data diatas akan dilakukan dengan langkah-langkah sebagai berikut: ${ }^{31}$

\footnotetext{
${ }^{29}$ Sugiyono, Metode Penelitian Administrasi (Bandung: Alfabeta, 2003), 111.

${ }^{30}$ Ibid.

${ }^{31}$ Rumus-rumus tersebut disesuaikan dengan penelitian kualitatif yang dilakukan oleh mahasiswa dari Seminari Theologia Baptis Indonesia Semarang.
} 
Menentukan jumlah skor jawaban partisipan dengan rumus: total skor jawaban $\mathrm{X}$ total pernyataan $\mathrm{X}$ total partisipan.

Jumlah skor jawaban partisipan adalah, 610 X 26 X $26=412.360$. Menentukan total skor ideal jawaban partisipan, yaitun skor yang diharapkan muncul (skor maksimal, dengan rumus: Total Skor Jawaban X Total Pernyataan X total partisipan. Sehingga diperolah skor idealnya adalah : (1X26X26) X 26 X $26=456.976$

Menentukan prosentase akhir jumlah skor partisipan dengan rumus sebagai berikut:

\section{Jumlah Skor Jawaban $\quad$ X 100\% \\ Skor Ideal}

Prosentase skor partisipan adalah:

$$
\begin{aligned}
& \frac{412.360}{456.976} \times 100 \% \\
= & 0.903 \times 100 \% \\
= & 90,30 \%
\end{aligned}
$$

Jika membandingkan prosentase jumlah skor partisipan yang diperoleh dengan criteria prosentase skor sebagai berikut: ${ }^{32}$

\begin{tabular}{|l|c|c|}
\hline No & $\begin{array}{c}\text { Interval } \\
\text { Prosentase }\end{array}$ & Kriteria \\
\hline 1 & $0-20$ & Sangat rendah \\
\hline 2 & $21-40$ & Rendah \\
\hline 3 & $41-60$ & Sedang \\
\hline 4 & $61-80$ & Tinggi \\
\hline 5 & $81-100$ & Sangat Tinggi \\
\hline
\end{tabular}

Jadi, prosentase partisipan: 90,30 \% dibandingkan dengan criteria prosentase di atas, maka prosentase tersebut katagorinya "sangat tinggi."

\section{KESIMPULAN}

Setelah dilakukan analisis untuk mendapatkan jawaban besarnya prosentase skor partisipan, maka dapat disimpulkan bahwa nilai implementasi pola pemuridan Yesus menurut Injil Matius di kalangan gembala sidang GPdI se-Kabupaten Jember adalah sangat tinggi, yaitu 90,30\%. Dari 26 Gembala sidang yang mengembalikan Angket, memberikan jawaban atas setiap pernyataan angket dengan lebih banyak menjawab "Ya". Berarti, para Gembala Sidang GPdI di Kabupaten Jember sudah menerapkan dengan baik tentang

${ }^{32}$ E. T. Ruseffendi, Dasar-dasar Penelitian Pendidikan dan Bidang Non-Eksakta Lainnya (Semarang: IKIP Semarang Press, 1994(Semarang: IKIP Semarang Press, 1994), 143. 
bagaimana memuridkan para pelayan di gereja masing-masing, mulai dari proses pemilihan murid, lalu bagaimana membentuk murid untuk mengikuti dan menjadi sama dengan Kristus, selanjutnya mengawasi setiap pelayanan murid serta pemberian kepercayaan dengan mengutus murid untuk memuridkan yang lain sehingga mengalami pelipatgandaan murid.

\section{REFERENSI}

Barna, George, The Power of Vision: Tanpa Visi Gereja Hancur. Malang: Gandum Mas, 2009.

Bartlett , David L., Pelayanan Dalam Perjanjian Baru. Jakarta: BPK Gunung Mulia, 2000.

Bible Work versi 8.

Browning, W. R. F., Kamus Alkitab, Panduan Dasar ke Dalam Kitab-kitab, Tema, Tempat, Tokoh dan Istilah Alkitabiah, Jakarta: BPK Gunung Mulia, 2009.

Byrne, Brian, Be My Disciple, Karakter Sejati Seorang Murid Kristus Abad-21.

Yogyakarta: ANDI Offset, 2010.

Coleman, Robert E., Rencana Agung Penginjilan. Bandung: Kalam Hidup, 1964.

Douglas, J. D, ed., Ensiklopedi Alkitab Masa Kini A-L. Jakarta: Yayasan Komunikasi Bina Kasih, 1997.

Eims, LeRoy, Penuai Yang Diperlengkap. Malang: Gandum Mas, 1988.

Enns, Paul, The Moody Handbook of Theology. Malang: Literatur SAAT, 2008.

Furchan, Arif, Pengantar Metode Penelitian Kualitatif. Surabaya: Usaha Nasional Indonesia, 1992.

Hull, Bill, The Complete Book of Discipleship on Being and Making followers of Christ. Colorado: NavPress, 2006.

Kamus Besar Bahasa Indonesia. Jakarta: Balai Pustaka, 1996.

Lebar, Lois E., Education That Is Christian: Proses Belajar Mengajar Kristiani \& Kurikulum Yang Alkitabiah. Malang: Gandum Mas, 2006

MacDonald, William, Pemuridan Sejati. Surabaya: Kasih Dalam Perbuatan, 2009. , Ikutilah Yesus! Pedoman Bagi Murid-murid Yesus. Sastra Hidup Indonesia, 2012.

Ruseffendi, E. T., Dasar-dasar Penelitian Pendidikan dan Bidang Non-Eksakta Lainnya.

Semarang: IKIP Semarang Press, 1994.

Semiawan, Conny R., Metode Penelitian Kualitatif. Jakarta: Grasindo, 2007.

Setiawani, Mary \& Tong, Stephen, Seni Membentuk Karakter Kristen: Hikmat Guru dan

Ayah Bunda. Jakarta: Lembaga Reformed Injili Indonesia, 1995.

Strong, James, Strong's Exhaustive Concordance of the Bible, Greek Dictionary of the

New Testament. USA: World Bible Publisher.

Sugiyono, Metode Penelitian Administrasi. Bandung: Alfabeta, 2003.

Tenney, Meril C, Survey Perjanjian Baru. Malang: Gandum Mas, 2000.

Wagner, C. Peter, Strategi Pertumbuhan Gereja. Malang: Gandum Mas, 1990.

Widiastuti, Kanti, Perkembangan Teologi Misi. Semarang: Sekolah Tinggi Theologia Baptis Indonesia, 2006.

Wiersb, Warren W., Seri Tafsiran Matius Loyal di Dalam Kristus Mengikut Raja Segala

Raja. Bandung: Kalam Hidup, 2012. 